\title{
Potential anti-proliferative effects of chemical constituents and hemisynthetic derivatives from Scadoxus psendocaulus (Amarillydaceae)
}

\author{
Annie Laure Ngankeu Pagning ${ }^{1,3}$, Jean-de-Dieu Tamokou², Bushra Taj Muhammad ${ }^{3}$, \\ David Ngnokam ${ }^{1}$, Leon AzefackTapondjou ${ }^{1}$, Mohammad Shaiq Ali³, Muhammad Waqar Hameed ${ }^{3}$
}

1. Research Unit of Environmental and Applied Chemistry, Department of Chemistry, Faculty of Science, University of Dschang, P O Box 183, Dschang, Cameroon.

2. Research Unit of Microbiology and antimicrobial Substances, Department of Biochemistry, Faculty of Science, University of Dschang, PO Box 067 Dschang, Republic of Cameroon.

3. International Center for Chemical and Biological Sciences, University of Karachi, Karachi-75270, Pakistan.

\section{Author e-mails:}

Annie Laure Ngankeu Pagning: apagning2000@yahoo.fr, Jean-de-Dieu Tamokou: jtamokou@yahoo.fr, Bushra Taj Muhammad: bushraistaj@gmail.com, David Ngnokam: dngnokam@yahoo.fr, Leon Azefack Tapondjou: tapondjou2001@yahoo.fr, Mohammad ShaiqAli: shaiq303@hotmail.com, Muhammad Waqar Hameed: mwaqar13@gmail.com

\begin{abstract}
Background: Biological significance of Amaryllidaceae is well advocated from the literature. In Cameroon, plants from this family are routinely used for the cure of liver, cancer and cardiovascular diseases. To date, no scientific investigation corresponding to the anti-cancer activity of extracts and isolated compounds of Scadoxus pseudocaulus is available.

Objective: Current study is focused to elaborate the anti-proliferative effects of natural isolates (compounds 1-6, 9) and hemi-synthetic analogs (compounds 7-8) extracted from $S$. pseudocaulu.

Methods: Column chromatography of the ethyl acetate extract followed by purification of different fractions led to the isolation of seven compounds $(1-6,9)$. Esterification reaction of compound 6 was carried out using butyroyl chlorides and triethylamin to produce two derivatives $(7-8)$. The cytotoxic activity was performed after staining of treated cells with florescent dye propidium iodide. Dead cells were detected using cytometer FL2 or FL3 channels/filters.

Results: Trans-derivative of narciclasine (a natural isolate from $S$. pseudocaulus), was found to be most potent among all tested compounds. Its effects were more significant on low malignant follicular lymphoma (DoHH2 cells) as compared to highly malignant (EBV infected) Burkitts lymphoma (Raji cells).

Conclusion: From our results, narciclasine appears to hold the potential of a lead molecule that can be used to bridge the therapeutic gaps in cancer research.

Keywords: Scadoxus pseudocaulus, Amaryllidaceae, 7-deoxy-trans-dihydronarciclasin, farrerol, derivatization, cytotoxic activity.

DOI: https://dx.doi.org/10.4314/ahs.v20i1.53

Cite as: Pagning ALN, Tamokon J--D , Muhammad BT, Ngnokam D, Tapondjou LA, Ali MS, et al. Potential anti-proliferative effects of chemical constituents and hemisynthetic derivatives from Scadoxus pseudocaulus (Amarillydaceae). Afri Health Sci. 2020;20(1):469-75. https:// dx.doi.org/10.4314/ahs.v20i1.53
\end{abstract}

\section{Corresponding author:}

Jean-de-Dieu Tamokou;

Research Unit of Microbiology and Antimicrobial

Substances, Department of Biochemistry,

Faculty of Science, University of Dschang,

P. O. Box 067 Dschang,

Republic of Cameroon;

Email: jtamokou@yahoo.fr /

jean.tamokou@univ-dschang.org

\section{Introduction}

Scadoxus pseudocaulus (I. Bjornstad and Friis), a member of the Amaryllidaceae, is used in the West Region of Cameroon, for the treatment of liver, cancer and cardiovascular diseases. Previous study demonstrated the antimicrobial, antioxidant and anti-butyrylcholinesterase activities of compounds and extracts of $S$. pseudocaulus. ${ }^{1}$ Apart from these biological activities, no conclusive scientific study is reported pertaining to its anti-cancer activity. It is known

CC 2020 Pagning ALN et al. Licensee African Health Sciences. This is an Open Access article distributed under the terms of the Creative commons Attribution License (https://creativecommons.org/licenses/BY/4.0), which permits unrestricted use, distribution, and reproduction in any medium, provided the original work is properly cited. 
that alkaloids of Amaryllidaceae family (likehe non-basic hydroxylated phenanthridones) possess high cytostatic activity. ${ }^{2-6}$ Some other alkaloids like galanthamine, lycorine and narciclasine can only be synthesized in plants of Amaryllidaceae family. ${ }^{7}$ Alkaloids from this family bear a number of biological activities including anti-microbial and anti-cancer. ${ }^{6}$ 7-deoxy-trans-dihydronarciclasin or trans-dihydrolycoricidin (5) is isocarbostyrl alkaloid reported from $S$. pseudocaulus like narciclasine (also known as lycoricidinol) who is known for its effects on protein biosynthesis. ${ }^{8}$ Narciclasine oil is effective in the treatment for uterine tumors. It also acts as a plant growth modulator. ${ }^{9}$ Narciclasine's first bioactivity was observed in 1967, where it was shown to have strong mitosis blocking activity. ${ }^{10}$ The reported biologically effects of narciclasine includes: anti-proliferative, antitumor/cytotoxic, acetylcholinesterase inhibitory, analgesic, hypotensive, antibacterial and antifungal. ${ }^{11}$ Data from studies on HeLa cell line showed that narciclasine and other alkaloids like lycorine, hidydrolycorine, haemanthanime, pretazettine and pseudolycorine can inhibit growth and protein synthesis. ${ }^{12}$ Not only narciclasine but also other alkaloid derivatives of Amaryllidaceae were reported to have anti-cancer effects. $^{13,14}$

However, narciclasine's group is found to be most potent and effective against cell growth and protein synthesis. ${ }^{6,15,16}$ Narciclasine is also found active on murine (p388 lymphoma) and human cancer cell lines (e.g. A549, NSCLC, PC3 and prostate). Narciclasine was also proposed as potential tool to cure apoptosis resistant metastasizing cancer cells. ${ }^{17}$ A study conducted on a panel of 60 human cancer cell lines showed narciclasine's potential cytotoxic effects. ${ }^{15}$ Another study reported anti-cancer effects of narciclasine on a variety of cancer cell lines, where fibroblasts were reported to be comparably resistant. ${ }^{18}$ Sensitivity of cancer cells to narciclasine was also reported using HUVECs (endothelial) cells. ${ }^{19}$ In a series of mechanistic studies, narciclasine was found to induce apoptosis driven cell death in cancer cells either mediated by the death receptors or mitochondria. ${ }^{18}$ It was further confirmed using human promyeloic (HL-60) cells and human oral cavity squamous carcinoma (HSC-2 cells) that it can induce apoptosis even at nano-molar concentrations. ${ }^{20}$ The above literature highlighted the significant biological effects of Amaryllidaceae family's natural isolates and hemi-synthetic derivatives and advocates further investigations to dis- cover their anti-cancer tendencies. Therefore, the current study aimed at evaluating the antiproliferative activities of isolated compounds and hemisynthetic derivatives from the whole plant of $S$. pseudocaulus.

\section{Materials and methods \\ Plant material}

Whole plant of Scadoxus psendocaulus was collected at Dschang, Menoua Division, West Region of Cameroon, in May 2013. The plant material was identified by Mr. Victor Nana, a botanist at the National Herbarium, Yaoundé, where a voucher specimen ( $\left.\mathrm{N}^{\circ} 34986 / \mathrm{SRF} / \mathrm{CAM}\right)$ was deposited.

\section{Extraction, isolation and hemi-synthesis of com- pounds}

The extraction and isolation of compounds were done as previously described. ${ }^{1}$ Briefly, $S$. pseudocaulus was air-dried and powdered. The powder was macerated at room temperature with $\mathrm{MeOH}$ to afford the $\mathrm{MeOH}$ extract. The $\mathrm{CHCl} 3$ and EtOAc fractions from the $\mathrm{MeOH}$ extract were collected by column chromatography. Purification of the EtOAc fraction yielded seven known compounds (Figure 1). Esterification reaction of compound 6 was carried out using butyroyl chlorides and triethylamin to produce two derivatives. The structures of isolated compounds and derivatives were determined thrugh NMR and MS. The data thus obtained was compared with those from the literature.

\section{Cytotoxicity assay}

To assess the anti-cancer potential of natural isolates and hemi-synthetic analogs, Burkitt's and Follicular lymphoma (B lymphoma) cell lines were selected. These cell lines were a gift from Prof. Dr. Daniel Hoessli, Switzerland and from Dr A. Kluin-Nelemans, Groningen, Netherlands, respectively. Monkey Vero cells (African green monkey kidney cells, normal non-cancer cells, ATCC No. CCL-81), obtained from the American Type Culture Collection (ATCC), was also used in this study. The cell lines were maintained at $37{ }^{\circ} \mathrm{C}$ in a humidified $5 \% \mathrm{CO} 2$ environment in Roswell Park Memorial Institute 1640 medium (RPMI; Caisson) with 1\% L-glutamine, 1\% penicillin/streptomycin (Gibco, Invitrogen), supplemented with 10\% foetal bovine serum (FBS, PAA laboratories). The cytotoxicity analysis was performed after staining of treated cells with florescent dye propidium iodide (PI) 
(excitation wavelength $=536 \mathrm{~nm}$; emission wavelength $=$ $617 \mathrm{~nm}){ }^{21,22}$ Principally, PI can't cross the intact plasma membrane and therefore, cannot stain live cells. However, after the cells have lost membrane integrity (i.e. dead cells), this dye enters into the cells and intercalate with the cellular DNA. Dead cells thus fluoresce and can be detected using cytometer FL2 or FL3 channels/filters. To generate dose response curve of the set of standard and test compounds, cells were seeded in a 96 well plate. Each well contains $0.13 \times 106$ cells in final reaction volume of $200 \mu \mathrm{L}$. Cells treated with bosutinib + RPMI 1640 served as positive control whereas cells left untreated + $0.5 \%$ (v/v) DMSO + RPMI 1640 were used as negative control.

\section{Statistical analysis}

Data was analyzed by one-way analysis of variance followed by Waller-Duncan Post Hoc test and Statistical
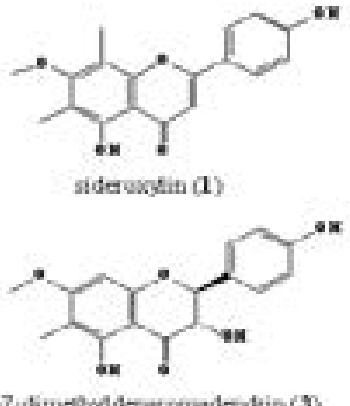

0.6,0-7.dimebyddantomadedein (3)

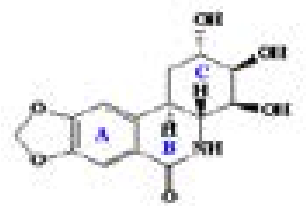

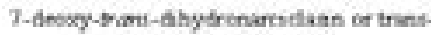
dihyoblomenation (\$)

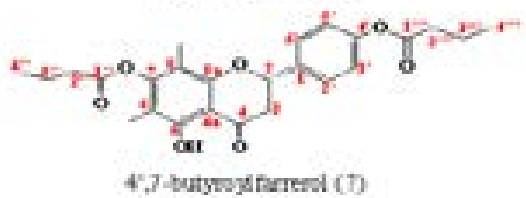

4,7-butyrogs farresd (7)
Package for Social Sciences software (SPSS, version 12.0). The results were expressed as mean \pm standard deviation (SD). Differences between groups were considered significant when $\mathrm{p}<0.05$.

\section{Results}

\section{Chemical analysis}

The phytochemical investigation of the $\mathrm{CHCl} 3$ and EtOAc fractions from the $\mathrm{MeOH}$ extract of S. pseudocaulus, afforded six known compounds namely sideroxylin (1),23 5-hydroxylmethyl-2-furancarboxaldehyde (2),24 C-6,O-7-dimethyldenaromadendrin (3),25 4-(hydroxymethyl)-5-hydroxy-2H-pyran-2-one (4),26 7-deoxy-trans-dihydronarciclasin or trans-dihydrolycoricidin (5),15 farrerol (6)25,27 and pinoresinol-4'-O- $\beta$-D-glucopyranoside (9).28 Esterification reaction of farrerol (6) was carried out using butyroyl chlorides and triethylamin to produce two derivatives namely 4',7-butyroylfarrerol (7) and 4'-butyroylfarrerol (8)1 (Figure 1).

5.mydroxylmeshyl -2 - tarancatoxaldehyde (2)

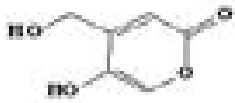

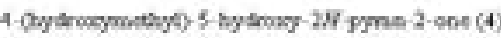
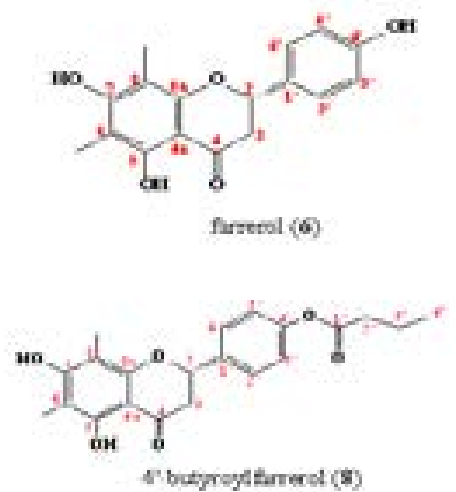

A. botyregttarreret (\$)

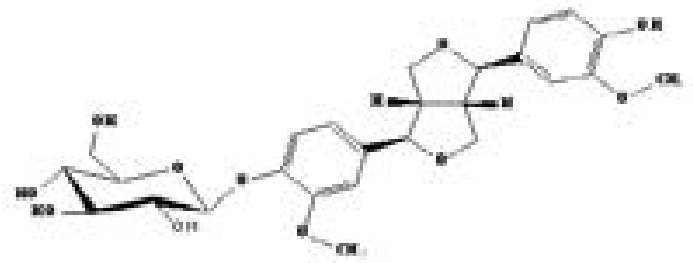

puncerenol -4':O,D.D.grocopgranade (9)

Fegure 1: Structures of lsolated compounds (1-6,9) and hemisyethetic derivarives (7-8) 


\section{Cytotoxic activities}

The cytotoxic activities of compounds ${ }^{1-9}$ were evaluated against two cancer cell lines and normal non-cancer cells (Vero cells) (Table 1, Figures $2-3$ ). Both cancer cell lines were found sensitive to all tested compounds (0.46 \pm 0.18 to $46.15 \pm 3.44$ ), however, the highest activity was observed for compound 5 (-deoxy-trans-dihydronarciclasin or trans-dihydrolycoricidin) (46.15 \pm 3.44 for Raji cells and 39.62 \pm 1.67 for DOHH2 cells) (Figures 2 - 3). For Raji cells, $114.47 \mu \mathrm{M}$ concentration of compound
5 was required for the induction of death in $50 \%$ cell population, however, $134.28 \mu \mathrm{M}$ were found sufficient for DoHH2 cells (Table 1). The test compounds were non-toxic to normal cells (results not shown) whereas the Selectivity Index (SI) values of the compound 5 against the Raji and DOHH2 cells cells are 13.07 and 11.14 indicating its good selectivity on the test cancer cell lines (Table 1). Bosutinib was used as a standard drug in the study. Its IC50 dose for Raji cells observed to be 63.17 $\mu \mathrm{M} \pm 3.65$ and for DoHH2 cells $68.30 \mu \mathrm{M} \pm 1.06$ after $48 \mathrm{hr}$ incubation time (Table 1).

Table 1: Cytotoxicity $\left(\mathrm{IC}_{50}\right)$ and Selectivity index (SI) of compound $\mathbf{5}$ against Raji and DOHH2 cells.

\begin{tabular}{|l|l|l|l|l|l|}
\hline \multirow{2}{*}{ Compounds } & \multicolumn{3}{|c|}{ Cytotoxicity $\left(\right.$ IC $_{50}$ in $\left.\boldsymbol{\mu M}\right)$} & \multicolumn{2}{c|}{ Selectivity index (SI) } \\
\cline { 2 - 6 } & Raji cells & DOHH2 cells & Vero cells & Raji cells & DOHH2 cells \\
\hline $\mathbf{5}$ & $114.47 \pm$ & $134.28 \pm 1.34^{\mathrm{b}}$ & $1496.46 \pm 1.84^{\mathrm{c}}$ & $13.07 \pm 1.71^{\mathrm{a}}$ & $11.14 \pm 0.98^{\mathrm{a}}$ \\
\hline & $0.53^{\mathrm{a}}$ & & & & \\
\hline Bosutinib & $63.17 \pm 3.65^{\mathrm{a}}$ & $68.30 \pm 1.06^{\mathrm{b}}$ & $1298.83 \pm 1.09^{\mathrm{c}}$ & $20.56 \pm 1.54^{\mathrm{a}}$ & $19.01 \pm 1.23^{\mathrm{a}}$ \\
\hline
\end{tabular}

SI: $\mathrm{IC}_{50}$ on Vero cells/IC 50 on cancer cells; ${ }^{*} \mathrm{SI}$ obtained from average $\mathrm{IC}_{50}$; each $\mathrm{IC}_{50}$ value represents the Mean $\pm \mathrm{SD}(\mathrm{n}=3)$; on the same line, $\mathrm{IC}_{50} / \mathrm{SI}$ values marked with different supersript letters are significantly different $(\mathrm{p}<0.05)$.

\section{Discussion}

The current investigation was carried out to evaluate the antiproliferative activities of isolated compounds and hemisynthetic derivatives from the whole plant of $S$. pseudocaulus. The findings of the present study revealed lesser sensitivity of Raji cells to compound 5 that can be due to EBV (Epstein Barr Virus) infection. This virus encodes a number of viral proteins that makes these cells resistant to apoptosis and promote growth. ${ }^{29-31}$ One of these proteins is latent membrane protein (LMP2A) that is membrane bound and shares structural resemblance to B cell surface receptor protein (BCR). LMP2A is known to play role in relaying survival signal thus promoting survival of B lymphoma cells. ${ }^{32-34}$

7-deoxy-trans-dihydronarciclasin, (an enantiomer) is a well reported potent anti-neoplastic agent. ${ }^{35}$ Trans derivative of narciclassine is found to be more active as compared to cis form. ${ }^{13}$-deoxy-trans-dihydronarciclasin has significant anti-cancer effects and the detailed SAR studies elucidated that this molecule has pharmacophore moiety which induces apoptosis. ${ }^{15,19,36-40}$ The tri-hydroxyl- ated ring $\mathrm{C}$ of this compound is also considered to be a critical part. In fact, the substitution of tri-hydroxylated ring $\mathrm{C}$ with hydrophobic moieties led to decrease in anti-cancer capacity and the same was observed upon loss of three hydroxyl groups. ${ }^{37,41-44}$ Thus, it could be seen that 7-deoxy-trans-dihydronarciclasin has significant cytotoxic effects and can induce apoptosis in cancer cell lines making it a lead molecule in cancer research. The antiproliferative effects of sideroxylin against ovarian cancer cells are through the induction of mitochondrial dysfunction and the activation of PI3 K and MAPK signal transduction. ${ }^{45}$ Selectivity Index (SI) of active compounds was determined in order to investigate, whether the cytotoxic activity was specific to cancer cells. The SI of the samples is defined as the ratio of cytotoxicity (IC50 values) on normal cells (Vero cells) to cancer cells: $\mathrm{SI}=\mathrm{IC}_{50}$ on Vero cells/IC50 on cancer cells. The Selectivity Index (SI) values of the compound 5 against the Raji and DOHH2 cells cells are 13.07 and 11.14 and could be considered as good when taking in consideration that the ratio for a good therapeutic index for a remedy or drug should be $\geq 10 .{ }^{46}$ These results are consistent with the use of compound $^{5}$ for treating $B$ lymphoma. 


\section{Conclusion}

Present investigation has revealed that isolated compounds and hemisynthetic derivatives from $S$. pseudocaulus are active against the tested cancer cell lines and non toxic against Vero cells (non-cancer cells). The pattern of response revealed that EBV infected Burkitt lympho$\mathrm{ma}$ is less sensitive to 7-deoxy-trans-dihydronarciclasin as compared to Follicular lymphoma. Greater cytotoxic effect on slow growing follicular lymphoma signifies its metabolic stability which can be exploited for slow progressing malignancies. Further investigations are needed to screen them against other cancer types and human cell line of normal tissues, including bone marrow cells to justify the traditional use of $S$. psendocaulus as an anticancer substance. Detailed mechanistic studies are also needed to find the mode of action of this compound on the molecular pathway(s) potentially leading to cell death.

\section{Acknowledgments}

This research work was supported under the umbrella of TWAS-ICCBS Postgraduate Fellowship Program. We are grateful to the University of Dschang for financing some consumable items used in this work.

\section{Conflict of interest}

None declared.

\section{References}

1. Ngankeu PAL, Tamokou JD, Khan ML, Ali MI, Hameed A, Ngnokam D, Tapondjou LA, Kuiate JR, Ali MS. Antimicrobial, antioxidant and butyrylcholinesterase inhibition activities of extracts and isolated compounds from Scadoxus pseudocaulus and semi-synthetic farrerol derivatives. South African Journal of Botany 2016; 102: 166174. doi.org/10.1016/j.sajb.2015.06.009

2. Hoshino O. In The Alkaloids; Cordell GA, Ed.; Academic: San Diego, CA, 1998; Vol. 51, pp 181-236.

3. Rinner U, Hudlicky T. Synthesis of Amaryllidaceae constituents-an update. Synlett 2005; 2005(03): 365-387. doi: 10.1055/s-2005-862382

4. Chapleur Y, Chretien F, Ibn Ahmed S, Khaldi M. Chemistry and synthesis of highly oxygenated alkaloids from Amaryllidaceae: lycoricidine, narciclasine, pancratistatin and analogs. Current Organic Synthesis 2006; 3(3): 341-378. doi : 10.2174/157017906777934872

5. Manpadi M, Kornienko A. Total syntheses of pancratistatin. A review. Organic Preparations and Procedures International 2008; 40(2): 107-161. doi: 10.1080/00304940809458083
6. Kornienko A, Evidente A. Chemistry, biology, and medicinal potential of narciclasine and its congeners. Chemical Reviews 2008; 108(6): 1982-2014. doi: 10.1021/ cr078198u

7. Diamond A, Desgagné-Penix I. Metabolic engineering for the production of plant isoquinoline alkaloids. Plant Biotechnology Journal 2016; 14(6):1319-1328. doi: 10.1111/ pbi.12494.

8. Garreau de Loubresse N, Prokhorova I, Holtkamp W, Rodnina MV, Yusupova G, Yusupov M. Structural basis for the inhibition of the eukaryotic ribosome. Nature 2014; 513: 517-522. doi: 10.1038/nature13737.

9. Riddle JM. Ancient and medieval chemotherapy for cancer. Isis1985; 76(3): 319-330. doi.org/10.1086/353876.

10. Ceriotti G. Narciclasine: an antimitotic substance from Narcissus bulbs. Nature 1967; 213: 595-596. doi: $10.1038 / 213595 \mathrm{a} 0$

11. He M, Qu C, Gao O, Hu X, Hong X. Biological and pharmacological activities of Amaryllidaceae alkaloids. Royal Society Chemistry Advances 2015; 5(21): 16562-16574. doi: 10.1039/c4ra14666B.

12. Jimenez A, Santos A, Alonso G, Vazquez D. Inhibitors of protein synthesis in eukaryotic cells: comparative effects of some Amaryllidaceae alkaloids. Biocbimica and Biophysica Acta (BBA)-Nucleic Acids and Protein Synthesis 1976: 425(3): 342-348.

13. Evidente A, Kireev AS, Jenkins AR, Romero AE, Steelant WF. Biological evaluation of structurally diverse Amaryllidaceae alkaloids and their synthetic derivatives: discovery of novel leads for anticancer drug design. Planta Medica 2009; 75(5): 501-507. doi: 10.1055/s-00291185340

14. Evidente A, Kornienko A. Anticancer evaluation of structurally diverse Amaryllidaceae alkaloids and their synthetic derivatives. Phytochemistry Reviews 2009; 8(2): 449459. doi: 10.1055/s-0029-1185340

15. Pettit GR, Pettit III GR, Backhaus RA, Boyd MR, Meerow AW. Antineoplastic agents, 256. Cell growth inhibitory isocarbostyrils from Hymenocallis. Journal of Natural Products 1993; 56(10): 1682-1687. doi: 10.1021/ np50100a004.

16. Ingrassia L, Lefranc F, Mathieu V, Darro F, Kiss R. Amaryllidaceae isocarbostyril alkaloids and their derivatives as promising antitumor agents. Translational Oncology 2008;1(1): 1-13.

17. Lefranc F, Dubois S, Ingrassia L, Van Quaquebeke E, Darro F, Kiss R. Narciclasine displays potent and selective anti-tumor effects by impairing cancer cell migra- 
tion through a phosphocofilin-mediated increase of actin stress fibers. Neuro-oncology 2008;10(6):1142.

18. Dumont $\mathrm{P}$, Ingrassia L, Rouzeau S, Ribaucour F, Thomas S, Roland I, Darro F, Lefranc F, Kiss R. The Amaryllidaceae isocarbostyril narciclasine induces apoptosis by activation of the death receptor and/or mitochondrial pathways in cancer cells but not in normal fibroblasts. Neoplasia, 2007; 9(9): 766-776.

19. Ingrassia L, Lefranc F, Dewelle J, Pottier L, Mathieu V, Spiegl-Kreinecker S, Sauvage S, El Yazidi M, Dehoux M, Berger W, Van Quaquebeke E. Structure-activity relationship analysis of novel derivatives of narciclasine (an Amaryllidaceae isocarbostyril derivative) as potential anticancer agents. Journal of Medicinal Chemistry 2009; 52(4): 1100-1114. doi: 10.1021/jm8013585.

20. Jitsuno M, Yokosuka A, Hashimoto K, Amano O, Sakagami H, Mimaki Y. Chemical constituents of Lycoris albiflora and their cytotoxic activities. Natural Product Communications 2011; 6(2): 187-192.

21. Boyd MR, Paull KD. 1995. Some practical considerations and applications of the National Cancer Institute in vitro anticancer drug discovery screen. Drug Development Research 1995; 34(2): 91-109. doi.org/10.1002/ ddr.430340203

22. Donnou S, Galand C, Touitou V, Sautès-Fridman C, Fabry Z, Fisson S. Murine models of B-cell lymphomas: promising tools for designing cancer therapies. $A d$ vances in Hematology 2012; Article ID 701704, 13 pages. doi:10.1155/2012/701704

23. Hillis WE, Isoi K. Variation in the chemical composition of Eucalyptus sideroxylon. Phytochemistry 1965; 4(4): 541-550. doi: 10.1016/s0031-9422(00)86214-7.

24. Pyo MK, Jin JL, Koo YK, Yun-Choi HS. Phenolic and furan type compounds isolated from Gastrodia elata and their anti-platelet effects. Archives of Pharmacal Research 2004; 27(4): 381-385.

25. Arthur HR. A new optically active flavanone from the leaves of Rhododendron farrerae, tate. Journal of the Chemical Society 1955; 0: 3740-3742. doi:10.1039/ JR9550003740.

26. Lin A, Lu X, Fang Y, Zhu T, Gu Q, Zhu W. Two new 5-hydroxy-2-pyrone derivatives isolated from a marine-derived fungus Aspergillus flavus. The Journal of Antibiotics 2008 ; 61(4): 245-249. doi: 10.1038/ja.2008.36.

27. Youssef DT, Ramadan MA, Khalifa AA. Acetophenones, a chalcone, a chromone and flavonoids from Pancratium maritimum. Phytochemistry 1998; 49(8): 2579-2583. doi: 10.1016/S0031-9422(98)00429-4
28. Ouyang M, Wein YS, Zhang ZK, Kuo YH. Inhibitory activity against Tobacco Mosaic Virus (TMV). Replication of pinoresinol and syringaresinol lignans and their glycosides from the root of Rhus javanica var.roxburghiana. Journal of Agricultural and Food Chemistry 2007: 55: 6460-6465. doi: 10.1021/jf0709808

29. Milner AE, Johnson GD, Gregory CD. Prevention of programmed cell death in burkitt lymphoma cell lines by bcl-2-dependent and-independent mechanisms. International Journal of Cancer 1992; 52(4): 636-644. doi: 10.1002/ ijc. 2910520424.

30. Imadome KI, Shirakata M, Shimizu N, Nonoyama S, Yamanashi Y. CD40 ligand is a critical effector of Epstein-Barr virus in host cell survival and transformation. Proceedings of the National Academy of Sciences 2003;100(13): 7836-7840. doi: 10.1073/pnas.1231363100.

31. Matusali G, Arena G, De Leo A, Di Renzo L, Mattia E. Inhibition of p38 MAP kinase pathway induces apoptosis and prevents Epstein Barr virus reactivation in Raji cells exposed to lytic cycle inducing compounds. Molecular Cancer 2009; 8(1): 18. doi: 10.1186/1476-4598-8-18.

32. Caldwell RG, Wilson JB, Anderson SJ, Longnecker R. Epstein-Barr virus LMP2A drives B cell development and survival in the absence of normal B cell receptor signals. Immunity 1998; 9(3): 405-411. doi.org/10.1016/ S1074-7613(00)80623-8.

33. Longnecker R. Epstein-Barr virus latency: LMP2, a regulator or means for Epstein-Barr virus persistence? Advances in Cancer Research 2000; 79: 175-200.

34. Merchant M, Caldwell RG, Longnecker R. The LMP2A ITAM is essential for providing B cells with development and survival signals in vivo. Journal of Virology 2000; 74(19): 9115-9124. doi: 10.1128/JVI.74.19.91159124.2000

35. Szántó G, Hegedûs L, Mattyasovszky L, Simon A, Simon Á, Bitter I, Tóth G, Tőke L, Kádas I. An expedient total synthesis of ent-(-)-7-deoxy-trans-dihydronarciclasine. Tetrabedron 2009; 65(40): 8412-8417. doi: 10.1016/j.tet.2009.07.092

36. McNulty J, Mo R. Diastereoselective intramolecular nitroaldol entry to lycoricidine alkaloids. Chemical Communications 1998; 0(8): 933-934. doi : 10.1039/A800097B.

37. McNulty J, Mao J, Gibe R, Mo R, Wolf S, Pettit GR, Herald DL, Boyd MR. Studies directed towards the refinement of the pancratistatin cytotoxic pharmacophore. Bioorganic \& Medicinal Chemistry Letters 2001; 11(2): 169172. doi: 10.1016/S0960-894X(00)00614-4

38. Pettit, GR, Eastham SA, Melody N, Orr B, Herald 
DL, McGregor J, Knight JC, Doubek D.L., Pettit GR, Garner LC, Bell JA. Isolation and structural modification of 7-Deoxynarciclasine and 7-Deoxy-trans-Dihydronarciclasine. Journal of Natural Products 2006; 69(1): 7-13. doi: $10.1021 / \mathrm{np} 0580681$

39. Pettit GR, Melody N, Herald DL, Knight JC, Chapuis JC. Antineoplastic Agents. 550. Synthesis of 10b (S)-Epipancratistatin from (+)-Narciclasine. Journal of Natural Products 2007; 70(3): 417-422. doi: 10.1021/np068046e.

40. McNulty J, Nair JJ, Griffin C, Pandey S. Synthesis and biological evaluation of fully functionalized seco-pancratistatin analogues. Journal of Natural Products 2008; 71(3): 357-363. doi: 10.1021/np0705460.

41. Mondon A, Krohn K. Chemistry of narciclasine. Chemische Berichte 1975; 108(2): 445-463.

42. Baez A, Vazquez D. Binding of $[3 \mathrm{H}]$ narciclasine to eukaryotic ribosomes A study on a structure-activity relationship. Biochimica et Biophysica Acta (BBA)-Nucleic Acids and Protein Synthesis 1978; 518(1): 95-103. doi. org/10.1016/0005-2787(78)90119-3.

43. Rinner U, Hillebrenner HL, Adams DR, Hudlicky
T, Pettit GR. Synthesis and biological activity of some structural modifications of pancratistatin. Bioorganic \& Medicinal Chemistry Letters 2004; 14(11): 2911-2915. doi: 10.1016/j.bmcl.2004.03.032.

44. McNulty J, Larichev V, Pandey S. A synthesis of 3-deoxydihydrolycoricidine: refinement of a structurally minimum pancratistatin pharmacophore. Bioorganic \& Medicinal Chemistry Letters 2005; 15(23): 5315-5318. doi: 10.1016/j.bmcl.2005.08.024.

45. Park S, Lim W, Jeong W, Bazer FW, Lee D, Song G. Sideroxylin (Callistemon lanceolatus) suppressed cell proliferation and increased apoptosis in ovarian cancer cells accompanied by mitochondrial dysfunction, the generation of reactive oxygen species, and an increase of lipid peroxidation. Journal of cellular Physiology 2018; 233(11): 8597-8604. doi: 10.1002/jcp.26540.

46. Caamal-Fuentes E, Torres-Tapia LW, Simá-Polanco P, Peraza-Sánchez SR, Moo-Puc R. Screening of plants used in Mayan traditional medicine to treat cancer-like symptoms. Journal of Ethnopharmacology 2011; 135: 719-724. doi: 10.1016/j.jep.2011.04.004. 